\title{
Detecting earnings management using Benford's Law: the case of Romanian listed companies
}

\author{
Costel Istrate ${ }^{\mathrm{a}, 1}$ \\ ${ }^{a}$ Alexandru Ioan Cuza University of Iași, Romania
}

\begin{abstract}
Research question: This study aims to identify possible cosmetic earnings management in the case of the Romanian listed companies. Motivation: According to the literature, the managers tend to overstate the net income presented in the financial statement. For the users of these documents and for the researchers, it is important to find out if the numbers they receive are reliable. Idea: Researchers use sometimes the Benford's Law which proposes normal frequencies for the appearance of the digit form 0 to 9 in different position of numbers. By comparing these normal frequencies with those actually observed, we can detect differences that suggest possible manipulations of net income. Data: The study take into consideration more than 1,200 observations concerning Romanian listed companies during the 20012017 period, divided in three sub-periods. Tools: We compare the real frequencies of the digits in the net income with the BL proposed frequencies, by sub-period, firm size, auditor category, type of audit opinion, and gender of the CFO. Findings: In general, the upward rounding of earnings are confirmed in a limited number of cases, even if the amplitude of these differences is often very important. The evolution of the accounting regulation leads to a situation where we start with rather downward manipulations, to arrive on the opposite direction. The IFRS transition seems to not lead to a limitation of the differences between the real frequencies and the normal ones. By separating the observations according to the size (total assets), we found that the bigger companies manipulate more upward the net income than the smaller ones. The companies audited by a Big $\mathrm{N}$ auditor report less upward manipulations. Women CFOs seems to be less prudent, the net income reported by these companies

${ }^{1}$ Corresponding author: Department of Accounting, Management Information Systems and Statistics, Faculty of Economics and Business Administration, Alexandru Ioan Cuza University of Iași, Iași, Bd. Carol 1, no. 22; tel. (+40) 23220 1599, istrate@uaic.ro
\end{abstract}


presenting more upward rounding. Contribution: Our findings contribute to the literature through a better understanding of the behaviour of Romanian listed companies, providing information about the situations in which users can expect some manipulation of reported financial indicators.

Keywords: (cosmetic) earnings management, Benford's Law, net income, Romanian listed companies, 2001-2017 period

\section{JEL codes: M40}

\section{Introduction}

The motivations behind the manipulations of the earnings (and of others financial indicators) often reflect pressures from some stakeholders (investors, creditors, and others), in the sense that the net income presented must be constant enough (if not increasing) from one year to the next, it must exceed the forecasts of the company and/or of financial analysts. Van Caneghem (2004) cites several studies that show that managers clearly tend to overstate the presented net income, rather than underestimate it. The extent to which entities manipulate the accounting information depends on several factors, including the ability of users to detect such manipulations (Vladu et al., 2017).

In identifying and measuring the manipulations of the accounting figures, several techniques are used, from the estimation of discretionary accruals to the audit opinion. A technique that allows us to identify possible manipulations is the comparison between the actual frequencies of the digits that form the numbers presented with the theoretical frequency provided by the Benford's Law (BL), firstly empirically observed by Newcomb, in 1881 (Lolbert, 2008; Riccioni \& Cerqueti, 2018). In fact, the application of this law shows us a particular form of earnings management - cosmetic earnings management - defined as the tendency of firms to round up positive earnings, so that the order of magnitude of the number is exceeded. The BL shows the normal frequencies of the appearance of the digits from 0 to 9 in the various positions of the number reported; an author (Lolbert, 2008) claims that "curiously enough, most empirical data-sets obey this law", even if changing the units used for measuring the data (from a currency to another, for example). When the actual distribution of digits in these numbers shows frequencies different from those proposed by the BL, we can assume that the respective numbers were manipulated in one direction or the other (Carslaw, 1999; Nigrini, 1999; Kinnunen \& Koskela, 2003; Van Caneghem, 2004; Guan et al., 2006 and 2008; Archambault \& Archambault, 2011; Jordan \& Clarck, 2011; Jordan et al., 2014; Dang \& He, 2017 etc.). When the firm seeks to round up the income, we can expect more frequent digits 1 or 5 on the first position of the number (Archambault \& Archambault, 2011), 
and also a more frequent appearance of the digit 0 (and possibly 1) in second position. In the literature, we found that in rounding upward the accounting numbers, the producers of the accounting information try to take advantage of the way users perceive differences between numbers. Most often, it is exemplified by the price of 1.99 , perceived as being much lower than a price of 2.00. Conversely, a profit of $1,000,000$ is perceived to be much larger than a profit of 998,000 . At the same time, the directors of listed firms often receive bonuses based on certain financial indicators, so they are directly interested in meeting the thresholds stipulated in the contracts. Jordan et al. (2014) argue that the manipulation of accounting number is present everywhere, but especially before the advent of stricter regulations on governance, financial reporting and auditing. Kinnunen and Koskela (2003) propose a similar conclusion. The BL is used in the analysis of accounting numbers to identify possible manipulations, but also to detect fraud, by auditors or by other persons (Hogan, 2008), or to identify errors in the preparation of financial statements or in other situations involving series of numbers (Amiram et al., 2015). The BL can be used in the analysis of non-accounting data, such as economic forecasts, macroeconomic data (such as GDP or inflation rates series) or financial market indexes, even if the grounding and applicability of BL remain highly debatable (Whyman et al., 2016).

The most frequent analysis in the literature concerns the presence of digits 0 and 9 in the second position of the numbers representing the net income of firms. The upward manipulation of positive earnings (profits) can be assumed when the frequency of appearance of the digit 0 is greater than that proposed by the BL and when the frequency of appearance of the digit 9 is lower than the normal. In the case of loss firms, the situation is reversed: less 0 and more 9 on the second position. At the same time, we find in the literature studies that take into consideration the digits 4 and 5: rounding up means that there are fewer 4 and more 5 in the second position of the numbers reporting net income.

Jordan et al. (2004) identify numerous studies that mobilize BL and demonstrate that this law represents a viable method for detecting manipulations of data. Moreover, there are attempts to use Benford's law in the analysis of data different than digits/numbers: Yan et al. (2018) propose a first-letter law that predicts the percentages of first letter for words in novels.

Our study aims to analyse the distributions of digits (especially 0 and 9, but also 1 and 8 , and 4 and 5) in the second position of numbers representing the net income reported by the Romanian listed companies during the period 2001- 2017, comparing them with the frequencies proposed by the BL. There are some studies in the literature that deal with the earning management by the Romanian listed companies, but to our knowledge, there are not yet any that use the BL in identifying possible manipulations of the reported net income. Our results, even if they show sometimes very large and inconsistent differences between the real frequencies and those of the 
BL, do not really confirm the hypothesis of the upward manipulation of the net income; the results must be taken with caution because there are some variables to take into account: profitable firms vs. loss firms, the evolution of the accounting regulation, companies' size, auditor category, audit opinion and even the gender of the person who holds the position of chief financial officer.

Our findings contribute to the literature through a better understanding of the behaviour of Romanian listed companies, providing information about the situations in which users can expect some manipulation of reported financial indicators.

The rest of paper contains a literature review (Section 2), the methodology and the population studied (Section 3), the main results (section 4), conclusions and references.

\section{Literature review}

In our literature review, we include studies using Benford's law (BL) to analyse how companies manipulate some accounting numbers, especially net income. In addition, in the case of Romanian listed companies, we have tried to identify the main findings of the studies analysing the manipulations of the net income by these companies.

\subsection{BL in the analysis of the accounting numbers}

Most of the studies that use BL in the analysis of the financial information reported by listed companies compute the frequency of the appearance of the different digits in second position of the these accounting numbers. There are studies that complement the analysis by presenting the frequencies of the digits appearing in the first position or by combining the frequencies of several digits. According to Shi et al. (2018), BL is largely used in the investigation of data manipulation in finance and economy, but also to verify the (non)reliability of macroeconomic data.

Carslaw (1988) is one of the first to mobilize the BL in accounting and financial research - he analyses the numbers reported by the New Zealand firms and, only for companies that have declared a profit - he finds significant differences between the real frequency and the expected frequency (proposed by the BL) of the digits appearing in second position. Thomas (1989), separating profit companies from loss companies, applies the methodology proposed by Carslaw (1988) to the American listed firms and also finds deviations from the normal distribution of the digits, although the differences are less important than in Carslaw (1988). Thomas (1989) extends the analysis to the quarterly results (with similar deviations observed as for the annual results) and the earnings per share, where the behaviour in the direction of rounding upwards seems more intense and with an abnormally high number of 
EPS divisible by 5 or by 10 . The comparison made by Thomas (1989) with the BL frequencies for the two categories of companies - profitable and unprofitable indicates the existence of potential manipulation of the reported incomes.

Kinnunen and Koskela (2003) provide a more comprehensive analysis of how BL can help identify the cosmetic earnings management, with a sample of nearly 22,000 firms from 18 countries (most of them from the United States), for the period 19951999. After the separation of profitable firms - loss firms, Kinnunen and Koskela (2003) confirm the worldwide presence of trends towards the manipulation of net income. In addition, Kinnunen and Koskela (2003) find that the evolution of the difference between actual and expected frequencies depends on audit fees, applied accounting standards, cultural characteristics and the importance of the bonuses. The country with the biggest differences between the actual and expected distribution of the 0 and 9 digits in second position of the net income is Spain, followed by Hong Kong and Singapore (Kinnunen and Koskela, 2003).

Skousen et al. (2004) retain 1.800 Japanese firms, for the 1974-1997 period, and find that Japanese managers very frequently round up the result, both by the manipulation of the first digit, the second one and even the third and fourth digit. These potential manipulations occur when the reported figures are close to the thresholds: management expectations, analyst's forecasts.

Van Caneghem (2004) analysis the British listed firms, in an attempt to find a link between the quality of auditing (proxied by the auditor's specialization by industry) and the tendency of firms to manipulate the net income upward. Van Caneghem (2004) eliminates the loss firms observations, as well as those with a single-digit income, and finds significant differences between the actual and normal distribution (BL), in the case of the numbers 0 and 9 in second position of the income before tax; nevertheless, for firms audited by a Big N specialized in the industry, the adjustments seem not to be significant.

Nigrini (2005) studies the impact of the Enron/Arthur Andersen bankruptcy and, based on the 2001 and 2002 reports of American firms, finds that the trend toward upward manipulation of accounting numbers is more limited than before, but it is still persistent: the analysis relates to net income, turnover and earnings per share. Aono and Guan (2008), for a four-year period, compare how US firms round up the net income before and after the SOX, comparing the frequency of the number 0 in second place. Guan et al. (2008) analyse a large population of American listed companies (for the 1950-2005 period), grouped into eight sectors of activity and identifies an unequal (depending on the sector) but persistent trend towards the upward rounding of the earnings.

Jordan et al. (2008) continues the analysis of Thomas (1989) and find that the managers of the loss firms no longer manipulate the income, whereas, for the 
profitable firms, the managers continue to do this, with a greater amplitude for the small companies, and independent of the leverage or the operation performances. One of the particularities of the study of Jordan et al. (2008) is that they propose several types of groupings of firms analysed: large vs. small, more leveraged vs. less leveraged, more profitable vs. less profitable.

Archambault and Archambault (2011), based on data published in 1915, analyse the financial behaviour of some American firms before the creation of the Securities and Exchange Commission (SEC), an environment without accounting and auditing standards, but with some regulation of certain industries. Archambault and Archambault (2011) uses the BL, checking the frequency of appearance of the digits 1 and 5 , on one side, and 4 and 9 , on the other, trying to identify possible manipulations upward or downward. The conclusions of Archambault and Archambault (2011) are in line with their expectations, that is to say that upward manipulations seem to be more present in the case of net income, for companies in non-regulated industries. At the same time, Archambault and Archambault (2011) find that there is a trend of undervaluation of commercial debts and manipulation of current assets, total assets and equity. On the other hand, for the companies whose activity is regulated, the net income does not seem to be manipulated, but some components of the profit and loss account and some balance sheet elements present differences compared to the BL frequencies.

Roxas (2011) uses in his analysis approximately 100 US companies that have received warnings from the SEC regarding the application of revenue recognition rules. The accounting numbers (quarterly income and earnings per share) used by Roxas (2011) relate to two years before and two years after the SEC's identification of the manipulations. The results of Roxas (2011) show that there is no direct relationship between firms designated as manipulators by the SEC: there are many of these firms whose distribution of digits does not necessarily follow the BL, but there are others for which the frequencies are very close to those expected.

Alali and Romero (2013) find that, in general, large firms are more inclined to manipulate financial information than small firms. He et al. (2013) draw on observations of American firms in the period 1950-2010 and analyse revenues and net income, separating profitable firms from loss companies. Differences between the real frequencies and the BL appear for both indicators, although the magnitude of these differences is greater for the revenues than for the income, for the profitable firms, while for the deficit firms, the opposite is true.

Jordan et al. (2014) analyse Canada's situation before and after the 2002 changes in the corporate governance regulation and conclude that this regulatory change is leading to a significant decrease in cosmetic earnings management for profitable firms. Geyer and Drechsler (2014) propose to check the correspondence with the BL 
for a balance sheet item - long-term debt - and find that US firms seem to manipulate numbers downwards.

Garza-Gomez et al. (2015) analyse the net income by business segments, presented by a sample of US firms, and find that the use of the numbers 0 and 9 in the second position moves away from the BL, in the case of profits; for losses, the two-digit frequencies approach the BL. Amiram et al. (2015) calculate a score based on normal distributions of BL: FSD (Financial Statement Divergence score) and demonstrate that many of the indicators presented in the financial statements correspond to the BL, but the most likely to manipulations are the indicators of the income statement, while the least manipulated are the numbers presented in cash flow. This analysis by Amiram et al. (2015) covers the period 2001-2011 and more than 43,000 observations. They also find that smaller, more recently created, more volatile and growing firms are more prone to manipulation.

Dang and $\mathrm{He}$ (2017) calculate the frequency of the emergence of the number 0 in the second position of the revenues and the interim income of certain Chinese listed firms; they identify much more 0 then expected in the second position in the case of profitable firms and significantly less 0 in the same position for firms with losses. In addition, for the Chinese firms analysed by Dang and He (2017), the manipulation seems more important after, than before the transition to IFRS.

For an emerging economy - Jordan - Bader and Saleh (2017) check how the numbers presented respect the distribution of the BL and find that firms present manipulated financial indicators mostly for sales and net profit (in the case of profitable firms), without identifying manipulations for firms reporting losses.

Ullman and Watrin (2017) consider that the application of the BL for the reported net income is useful when seeking to identify earnings management. Kumar et al. (2018) retain 5 variables for which the distribution of the digits is analysed: sales, operating income, net income, earnings per share and dividends per share. Verification of the normality of the distribution is done by using a FSD (Financial Statement Deviation) score based on the MAD (Mean Absolute Deviation), and taking into account all the digits from 0 to 9 . After the application of these tests, Kumar et al. (2018) find that all the variables analysed seem to be manipulated, for firms reporting losses, whereas, for firms reporting profits, similarities between actual frequencies and that of the BL appear only for sales and operating income.

In a different context, Riccioni and Cerqueti (2018) applied the BL to verify the distributions of the first and second digits in all the indexes provided by the stock exchanges of several countries, finding and commenting some discrepancies.

Skousen (2004) warns us that, in general, the rounding up of figures presented is a practice present in the behaviour of firms only when the profits exceed the costs of these manipulations. 


\subsection{Earnings management for the Romanian listed companies}

The earnings management literature on the Romanian listed companies includes some studies that have applied consecrated methodologies to samples of Romanian firms ${ }^{\mathrm{i}}$. Since, as of 2012, listed firms are required to apply IFRS in their individual financial statements, most studies analyse the situation before and after the transition to IFRS. Brad et al. (2014) note that the transition to IFRS has led to a significant improvement in the quality of accounting information published by Romanian listed firms, with respect to the variability of net income, cash flow, and the correlation between accruals and cash flows; Brad et al. (2014) conclude that the transition to IFRS has reduced the manipulation of net income in the year of transition (2012), especially for firms audited by Big 4 .

Balaciu et al. (2015), following a series of interviews with financial auditors, note that they consider that creative accounting practices are common in Romanian firms and that the main beneficiaries of manipulations of earnings are the managers. Carp (2015) analyses a sample of Romanian listed companies, for the period 2009 - 2013 and finds that these firms have similar behaviours to those of other economic areas, with an intensification of earnings management in the case of leveraged firms and of firms with higher net income, with a downward trend after the application of IFRS. By measuring the quality of the financial presentation by the dimensions of the accruals, Gajevsky (2015) also finds that the transition to IFRS has improved accruals.

Burcă and Mateş (2015) analyse the quality of the financial information provided by Romanian listed firms and note a slight improvement in the quality of the reported net income due to the application of IFRS. At the same conclusion comes Nechita (2015). Istrate et al. (2015) find that the transition to IFRS has reduced discretionary accruals and the presence of earnings management techniques is greater for negative discretionary accruals.

Huian et al. (2018) analyse 67 listed Romanian firms, for the period 2006-2015, and conclude that the earnings management is more present in the case of firms that use the indirect method for the presentation of operating cash flow. Ivan (2015) identifies techniques for manipulating cash flow, especially by shifting from one flow category to another.

None of the studies cited in this subsection discuss the distribution of digits in the net income or other financial indicators. The criteria used by the authors in the selection of samples are slightly different from one study to another, as well as the periods studied. The BL is used on the Romanian context by Druică et al. (2018): they do not analyse accounting data, but four types of aggregated Romanian bank deposit. 


\section{Methodology, data and hypotheses}

The study analyse the companies listed on the Bucharest Stock Exchange (BSE) during the period 2001-2017. The data are manually extracted from the individual financial statements - there are few that report consolidated financial statements: less than half. The number of non-financial companies is different from one year to another, but it stabilizes around 70, for the last years (Table 1). At the end of 2017, there were 87 firms listed on the BVB and there were a maximum of $100 \mathrm{firms}$ (including financial companies), along the interval. We eliminated the financial companies, as well as those for which the information was incomplete. For some calculations, the number of firms analysed is even smaller: because of the unavailability of audit reports, for example. In every table presenting the results of our analysis, we will provide the number of observations.

Table 1: The sample, by year

\begin{tabular}{lcrrrrrr}
\hline \multirow{2}{*}{ Year } & \multirow{2}{*}{$\begin{array}{c}\text { Accounting } \\
\text { standards }\end{array}$} & Observations & \multicolumn{3}{c}{$\begin{array}{c}\text { Profitable } \\
\text { companies }\end{array}$} & \multicolumn{2}{c}{ Loss companies $^{\mathrm{ii}}$} \\
\cline { 4 - 8 } & & & $\mathbf{N}$ & $\mathbf{\%}$ & $\mathbf{N}$ & $\mathbf{\%}$ \\
\hline 2017 & IFRS & 73 & 47 & 64.38 & 26 & 35.62 \\
2016 & IFRS & 74 & 56 & 75.68 & 18 & 24.32 \\
2015 & IFRS & 73 & 54 & 73.97 & 19 & 26,03 \\
2014 & IFRS & 75 & 55 & 73.33 & 20 & 26.67 \\
2013 & IFRS & 76 & 53 & 69.74 & 23 & 30.26 \\
2012 & IFRS & 76 & 53 & 69.74 & 23 & 30.26 \\
2011 & RAS & 79 & 59 & 74.68 & 20 & 25.32 \\
2010 & RAS & 79 & 56 & 70.89 & 23 & 29.11 \\
2009 & RAS & 80 & 61 & 76.25 & 19 & 23.75 \\
2008 & RAS & 79 & 64 & 81.01 & 15 & 18.99 \\
2007 & RAS & 81 & 71 & 87.65 & 10 & 12.35 \\
2006 & RAS & 73 & 64 & 87.67 & 9 & 12.33 \\
2005 & IAS & 71 & 62 & 87.32 & 9 & 12.68 \\
2004 & IAS & 71 & 63 & 88.73 & 8 & 11.27 \\
2003 & IAS & 59 & 53 & 89.83 & 6 & 10.17 \\
2002 & IAS & 51 & 44 & 86.27 & 7 & 13.73 \\
2001 & IAS & 45 & 37 & 82.22 & 8 & 17.78 \\
\hline Total & & $\mathbf{1 , 2 1 5}$ & $\mathbf{9 5 2}$ & $\mathbf{7 8 . 3 5}$ & $\mathbf{2 6 3}$ & $\mathbf{2 1 . 6 5}$ \\
\hline & & & & & &
\end{tabular}

We chose to divide the interval into three sub-periods ${ }^{\mathrm{iii}}$ :

- from 2001 to 2005 - IAS sub-period: the standards applied were "harmonized with International Accounting Standards and with European Directives"; in fact, 
this time interval represents the first contact of Romanian accountants with the terminology, vocabulary and philosophy of international standards (IAS, at the time). It must be said that these rules were almost completely new for the Romanian accountants and that their assimilation and their application were not done in an impeccable way - there were many approximations in the application of the rules (Istrate, 2006), many mistakes, which meant that for many companies, the quality of financial presentation was low;

- from 2006 to 2011 - RAS (Romanian accounting standards) sub-period: Romanian firms (including listed companies) applied standards in line with European directives, with some elements taken directly from IAS/IFRS; meanwhile (in 2007), Romania joined the EU, which make mandatory the application of IFRS in the consolidated financial statements of listed companies;

- from 2012 to 2017 - IFRS sub-period: the Romanian authorities have decided that, from 2012, the individual financial statements of all companies listed on the regulated market must comply with IFRS - this time, despite the extremely short period of preparation of the transition, the application of IFRS is made more seriously ${ }^{\text {iv }}$.

The companies in our sample present the financial statements in national currency and we had to transform certain amounts in new currency (RON) - following the 2005 monetary reform. At the same time, we multiplied by thousand the indicators of the firms which present in thousands of lei, in order to rank companies in ascending order of total assets.

The indicators analysed in the studies that mobilize BL are quite diverse. Most often we find the net income, but we also have the income before tax, the operating income, the income before the continued operations, the earnings per share, the earning attributed to ordinary shares (the numerator of the calculation formula of the earnings per share), the comprehensive income. There are also studies that take into account the revenues (Carslaw, 1998; He et al., 2013; Bader \& Saleh, 2017; Dang \& He, 2017), cash flows (Ullman \& Watrin, 2017), long-term debts (Geyer \& Drechsler, 2014). The study analysing the most indicators is that of Archambault and Archambault (2011): sales, gross margin, operating expenses, depreciation, fixed costs, net income, preferential dividends.

In our study, the analysis focuses only on the net income, but we will take into account several other variables: period, size, auditor category, audit opinion, gender of CFO. In all cases, we will provide the data for the total number of observations, but also for the profitable firms and for the loss firms.

The frequencies proposed by the $\mathrm{BL}^{\mathrm{v}}$ for the appearance of first and second digit in the numbers that form non-random series are presented in Table 2. Nigrini (2005) reminds us of the conditions under which the BL can be correctly applied: the 
numbers retained must describe similar events, the series of numbers must not have integrated minima or maxima, the numbers must not be assigned (such as account lists, personal codes etc.).

Table 2: Expected frequencies for the first and the second digits of a number, according to BL

\begin{tabular}{ccc}
\hline Digit & $\begin{array}{c}\text { Expected frequencies of } \\
\text { appearance in first position } \\
(\%)\end{array}$ & $\begin{array}{c}\text { Expected frequencies } \\
\text { of appearance in second } \\
\text { position (\%) }\end{array}$ \\
\hline 0 & - & 11.97 \\
1 & 30.10 & 11.39 \\
2 & 17.61 & 10.88 \\
3 & 12.49 & 10.43 \\
4 & 9.69 & 10.03 \\
5 & 7.92 & 9.67 \\
6 & 6.69 & 9.34 \\
7 & 5.80 & 9.04 \\
8 & 5.12 & 8.75 \\
9 & 4.58 & 8.50 \\
\hline Total & $\mathbf{1 0 0 . 0 0}$ & $\mathbf{1 0 0 . 0 0}$ \\
\hline
\end{tabular}

(Source: Nigrini, 2005)

In the analysis of the frequency of the digits, the inclusion of a single digit may lead to non-significant results; thus, Skousen et al. (2004) retain the differences between real-frequency and the normal frequencies, for groups of two or three digits, by grouping 0 and 1 and 9 and 8 (and even 7), in the second position and also compare the frequencies of digits 4 and 5 .

In our study, we will limit ourselves to analysing the frequencies of the digits 0 and 9 in second position, sometimes adding the digit 1 to the digit 0 and the digit 8 to the digit 9. When the differences between the actual distribution and that of the BL seem significant, we will also comment on the digits 4 and 5 .

Given that the main results presented in the literature indicate, in general, the appearance of possible manipulations in the direction of the rounding up of reported net income (more 0 and less 9 in second position profits, and less 0 and more 9 in second position for losses), we will propose hypothesis 1 :

Hla: The digit 0 (alone or grouped with the digit 1) appears in second position of the net income of the Romanian listed companies more frequently than the distribution according to the BL, and the digit 9 (alone or with the digit 8) appears less frequently than Benford's law suggests, in the case of firms declaring a profit. For loss firms, digits 0 and 1 are less frequent and the digits 9 and 8 more frequent than in $B L$. 
H2b: The evolution of Romanian accounting standards, and in particular the transition to IFRS, leads to a decrease in time of the differences between the real frequencies and the BL frequencies of the digits in the numbers reflecting the net income.

The size of firms (total assets, sales, market capitalization) are important in the assessment of performance and earnings management. Jordan et al. (2008) believe that dimensions are an important discriminating factor in the analysis of the manipulation of financial indicators. Kinnunen and Koskela (2003) introduce this variable into the analysis of net income digits. Alali and Romero (2013) classify firms by total assets. We will apply the same criterion, by separating small firms (below the median of total assets) from large firms (whose assets exceed the median).

H2: In the case of larger firms, the net income is less manipulated than in the case of the smaller firms, which translates, for large firms, into smaller differences between the real frequencies and the BL frequencies of the digits in the net income.

In identifying potential manipulations of the earnings, an independent variable used often is the auditor category: Big N vs non-Big N ${ }^{\mathrm{vi}}$. Van Caneghem (2004) takes this variable into account (i.e. separates the firms audited by Big Ns from the others) and finds that in both cases, the digits 0 and 9 in the second position are over-, respectively, under-represented, with, nevertheless, less important differences in the case of firms audited by Big N. In turn, Alali and Romero (2013) find, by analysing the real frequencies compared to those of the BL, that a decline in the quality of the financial presentation is observed especially in the case of firms audited by non-Big $\mathrm{N}$, which do not have well integrated audit requirements. We propose to verify the influence of the Big N/non-Big N auditors to the differences between the real and expected frequencies.

H3: Companies audited by Big $N$ exhibit less variation than the others between the actual distribution and the BL distributions of digits 0 and 1, respectively, 9 and 8, in the second position of the net income.

The literature finds that women and men who are CFOs in listed firms have different behaviours with regard to possible manipulation of earnings. Peni and Vähämaa (2010) find that firms whose chief financial officer is a woman have discretionary accruals that reduce earnings, which means that they choose more conservative accounting rules. Barua et al. (2010) propose similar findings: firms whose CFO is a woman have fewer discretionary accruals, in a context where the number of women entering the accounting profession is increasing. Taking into account these results and the fact that, in Romanian accounting, women are very numerous (Del Baldo et al., 2019), we formulate the following hypothesis.

H4: Firms with a female CFO have lower differences between actual frequencies and the BL for the second digit of the net income. 


\section{Results and discussions}

In the following tables, we will present the differences between the real frequencies and the expected frequencies proposed by the BL. We applied the Z-test and these differences only appear significant in a limited number of cases ${ }^{\mathrm{vii}}$. We will still present and comment them, like Jordan et al. (2008).

\subsection{Differences real vs. expected frequencies of the digits in the net income, by sub-period}

In Table 3, we present the results of the differences between the real frequencies and the expected BL frequencies of the digits appearing in the second position of the net income, for the Romanian companies listed on BSE, for the whole interval, and for each sub-period. Our expectations, based on the results proposed by the literature so far, in the sense of more 0 and less 9 in second position are not confirmed, when we analyse the entire interval. On the contrary, the 0 appears less often $(-0.12 \%)$ and the 9 more often $(0.31 \%)$, with very small differences, which would suggest that there is not too much upward manipulations. Even taking into account the numbers 1 and 8 , respectively (for which the frequencies are in the direction of our expectations), the differences remain insignificant. To find differences that partially confirm our expectations, we must go to digits $4(-1.22 \%)$ and $5(+0.86 \%)$, whose frequencies may suggest an upward manipulation of the income. For profitable firms, there are less 9 and 8 and less 0 , offset by more 1 . There too, we are far enough to detect significant differences in the sense of our hypothesis H1a. In the case of loss firms, we expect less 0 and more 9: in the case of 0 , this is not the case, but the possible manipulation can be observed when taking into account the digit 1: the compensation between the two-digit specific deviations shows a tendency towards the rounding upward net income. On the other hand, the digit 9 appears much more often than the normal situation and, even if the difference of its frequency is strongly compensated by less 8 , the general tendency remains towards an upward manipulation. In the case of digits 4 and 5, their frequencies for loss firms did not suggest an increase in the net income.

When analysing the first sub-period (IAS) - 2001-2005 - we find significant differences for almost all the digits and the sense of the deviations suggests rather an orientation towards the downward manipulation of the income (less 0, 1 and 2 and more 9). It is only at the level of digits 4 and 5 that our hypothesis seems confirmed (less 4, more 5). The situation is almost identical for profitable firms, with larger differences. This trend can be explained by the fact that the application of IAS was at the beginning and was done in a rather approximate way. Another explanation is that, at the time, the de facto connection between accounting and taxation was very strong (and with a high rate of income tax), which meant that companies preferred lowering the income in order to pay less tax. An alternative explanation for this trend 
towards diminishing the income is provided by Jiang et al. (2018), which shows that Chinese firms are encouraged to report smaller incomes in order to obtain public subsidies more easily. We do not have the necessary data to test such a hypothesis for the Romanian firms analysed, but we found that for many companies listed on the BSE, the State was an important shareholder. In the case of loss firms, more 9 seem to suggest upward rounding of the income (reduction of the losses), but this is not confirmed by less 0 . There too, the following digit (1) must be taken into account to identify a certain trend towards the reduction of losses.

Table 3 - Differences between actual BL frequencies for the appearance of the digits in the second position of the net income, by sub-period

\begin{tabular}{|c|c|c|c|c|c|c|c|c|c|c|}
\hline The digit & 0 & 1 & 2 & 3 & 4 & 5 & 6 & 7 & 8 & 9 \\
\hline $\begin{array}{l}\text { BL } \\
\text { Frequency } \\
(\%)\end{array}$ & 11.97 & 11.39 & 10.88 & 10.43 & 10.03 & 9.67 & 9.34 & 9.04 & 8.75 & 8.50 \\
\hline \multicolumn{11}{|c|}{ Panel 1: Differences real frequencies - BL expected frequencies, for the entire period analysed (2001-2017) } \\
\hline $\begin{array}{l}\text { Total obs. } \\
(N=1,215)\end{array}$ & -0.12 & 0.05 & -0.92 & 0.35 & -1.22 & 0.86 & 0.29 & 1.33 & -0.93 & 0.31 \\
\hline $\begin{array}{l}\text { Profitable } \\
\text { firms } \\
(\mathrm{N}=952)\end{array}$ & -0.84 & 1.00 & -0.80 & 0.18 & -1.00 & 0.41 & 0.43 & 1.78 & -0.56 & -0.62 \\
\hline $\begin{array}{l}\text { Loss firms } \\
(N=263)\end{array}$ & 2.48 & -3.41 & -1.37 & 0.98 & -2.05 & 2.50 & -0.21 & -0.29 & -2.29 & 3.67 \\
\hline \multicolumn{11}{|c|}{ Panel 2: Differences real frequencies - BL expected frequencies, for the IAS sub-period (2001-2005) } \\
\hline $\begin{array}{l}\text { Total obs. } \\
(\mathbf{N}=297)\end{array}$ & -2.21 & -1.29 & -2.46 & 2.36 & -2.96 & 0.77 & 0.76 & 2.74 & 0.00 & 2.27 \\
\hline $\begin{array}{l}\text { Profitable } \\
\text { firms } \\
(\mathbf{N}=259)\end{array}$ & -3.09 & -0.97 & -1.61 & 2.70 & -2.31 & 1.14 & -1.23 & 2.93 & 0.90 & 1.54 \\
\hline $\begin{array}{l}\text { Loss firms } \\
(\mathbf{N}=38)\end{array}$ & 3.82 & -3.50 & -8.25 & 0.10 & -7.40 & -1.78 & $\begin{array}{c}14.3 \\
4 \\
\end{array}$ & 1.49 & -6.12 & 7.29 \\
\hline \multicolumn{11}{|c|}{ Panel 3 - Real Frequency Difference - BL Frequencies, for the RAS period (2006-2011) } \\
\hline $\begin{array}{l}\text { Total obs. } \\
(\mathrm{N}=471)\end{array}$ & 1.41 & -0.35 & -0.26 & -0.45 & -0.90 & 0.73 & -0.85 & 1.36 & -0.68 & -0.01 \\
\hline $\begin{array}{l}\text { Profitable } \\
\text { firms } \\
(\mathbf{N}=\mathbf{3 7 5})\end{array}$ & 0.56 & 0.08 & -1.28 & -0.83 & -0.70 & 1.26 & -0.01 & 1.36 & -0.75 & 0.30 \\
\hline $\begin{array}{l}\text { Loss firms } \\
(\mathrm{N}=96)\end{array}$ & 4.70 & -2.02 & 3.70 & 1.03 & -1.70 & -1.34 & -4.13 & 1.38 & -0.42 & -1.21 \\
\hline \multicolumn{11}{|c|}{ Panel 4 - Real Frequency Difference - BL Frequencies for the IFRS period (2012-2017) } \\
\hline $\begin{array}{l}\text { Total obs. } \\
(\mathrm{N}=447)\end{array}$ & -0.34 & 1.36 & -0.59 & -0.14 & -0.41 & 1.07 & 1.17 & 0.36 & -1.81 & -0.67 \\
\hline $\begin{array}{l}\text { Profitable } \\
\text { firms } \\
(\mathbf{N}=\mathbf{3 1 8})\end{array}$ & -0.65 & 3.70 & 0.44 & -0.68 & -0.28 & -1.18 & 2.30 & 1.34 & -1.52 & -3.47 \\
\hline $\begin{array}{l}\text { Loss firms } \\
\text { (129) }\end{array}$ & 0.43 & -4.41 & $-3,13$ & 1.20 & -0.73 & 6.61 & -1.59 & -2.06 & -2.55 & 6.23 \\
\hline
\end{tabular}

The second sub-period (RAS: 2006-2011) shows that, for profitable firms and for the total sample, the hypothesis of upward manipulation of the net income is only partially confirmed, but in a larger measure than in the previous sub-period: the distribution of the digits $0(+0.56)$ and $9(-0.01)$ is not likely to make us believe in too much manipulation; even adding the frequencies of the digits 1 and 8 , we remain 
pretty much in the same pattern. It is always the distributions of the digits 4 and 5 that support our hypothesis. Loss firms have contrasting frequencies that seem to mark downward adjustments (more 0 , less 9 and 8 ).

Many studies find that the transition to IFRS (our third period: 2012-2017) has resulted in a better quality of the financial presentation, even if there is evidence to the contrary - an extensive literature review to this end provides us with De George and Shivakumar (2016). In our study, we expected, first, a closer results comparing with others studies, and, secondly, fewer differences between the real frequencies and the BL ones. In fact, there is significantly less 9 (and 8) and, also, less 0 , for profitable firms and for the total. For our hypothesis to be partially confirmed, we must take into account the frequency of the digit $1(+3.70$, respectively, +1.36$)$, which largely offsets the differences of the digit 0 . Thus, the transition to IFRS seems to lead not to less manipulation, but to more upward manipulations of the income, such as is found in mature financial markets; a similar conclusion is proposed by Lacina et al. (2018), in analysing the effect of the Korean financial reform on the cosmetic earnings management. The same thing is seen for the loss firms: much less $1(-4.41)$ which largely compensates the more $0(+0.43)$ and more 9 - it seems, here too, that the rounding of the net income is upward. Regarding the dimensions of the possible manipulations (upwards or downwards), we calculated the standard deviation of the differences between the real distributions and BL distributions (not reported in the tables): these standard deviations are very important for the IAS subperiod (2001-2005), they decrease significantly during the second sub-period (RAS: 2006-2011), to become more important in the IFRS sub-period. Thus, our H1b hypothesis is only partially confirmed: there has been a decrease in differences, but the IFRS period shows more gaps than the previous period.

\subsection{Differences real vs. expected frequencies of the digits in the net income, according to the companies' size}

In comparing the actual frequencies of the digits in the net income of the Romanian listed companies with the BL distribution, we did not continue with the three subperiods proposed in the previous sub-sections, because that would have led to a too small number of observations for certain intervals. The separation of small firms vs. large firms was done according to the total assets: firms with assets below the median are called small firms, the others (assets > median) fall into the second category: big companies. In Table 4, the differences for the total sample are the same as in Table 3 , since the number of total observations and the period remain the identical. For small firms, the sense of the differences between the real and expected frequencies is the same as for the whole sample, even if they are more significant: less 0 and more 9 , partly compensated by more 1 and more 8 . The upward manipulation is not confirmed for these companies, except in the case of digits 4 and 5, whose frequencies clearly indicate possible upward manipulations. For firms reporting profits, any upward manipulations seem not to concern the number $0(-2.60$, that is 
to say a possible reduction of the income), but the numbers 9 and 8 , whose frequencies suggest rounding upwards and, again, the numbers $4(-1.91)$ and 5 $(+2.21)$. For loss-making firms, more 0 and even more 9 , much less 4 and more 5 do not allow us to identify a coherent sense of possible manipulation.

Table 4 - Differences between real frequencies and BL frequencies for the appearance of the digits in the second position of the net income, according to the size of the firms

\begin{tabular}{|c|c|c|c|c|c|c|c|c|c|c|}
\hline The digit & $\mathbf{0}$ & 1 & 2 & 3 & 4 & 5 & 6 & 7 & 8 & 9 \\
\hline $\begin{array}{l}\text { BL } \\
\text { Frequencies }\end{array}$ & 11.97 & 11.39 & 10.88 & 10.43 & 10.03 & 9.67 & 9.34 & 9.04 & 8.75 & 8.50 \\
\hline \multicolumn{11}{|c|}{ Panel 1 - Differences Real frequency - BL frequencies, for total period analysed (2001-2017) } \\
\hline $\begin{array}{l}\text { Total obs. } \\
(\mathrm{N}=\mathbf{1 , 2 1 5})\end{array}$ & -0.12 & 0.05 & -0.92 & 0.35 & -1.22 & 0.86 & 0.29 & 1.33 & -0.93 & 0.31 \\
\hline $\begin{array}{l}\text { Profitable } \\
\text { companies } \\
(\mathbf{N}=952)\end{array}$ & -0.84 & 1.00 & -0.80 & 0.18 & -1.00 & 0.41 & 0.43 & 1.78 & -0.56 & -0.62 \\
\hline $\begin{array}{l}\text { Loss firms } \\
(\mathrm{N}=\mathbf{2 6 3}) \\
\end{array}$ & 2.48 & -3.41 & -1.37 & 0.98 & -2.05 & 2.50 & -0.21 & -0.29 & -2.29 & 3.67 \\
\hline \multicolumn{11}{|c|}{ Panel 2 - Differences Real frequency - BL frequencies, for small firms (below median) } \\
\hline $\begin{array}{l}\text { Total obs. } \\
(\mathrm{N}=608)\end{array}$ & -1.28 & 0.29 & -0.02 & -0.40 & -2.96 & 2.01 & 1.35 & 0.83 & -1.18 & 1.37 \\
\hline $\begin{array}{l}\text { Profitable } \\
\text { firms } \\
(N=\mathbf{4 8 0})\end{array}$ & -2.60 & 0.28 & 0.16 & 0.20 & -1.91 & 2.21 & 1.49 & 1.79 & -1.25 & -0.38 \\
\hline $\begin{array}{l}\text { Loss firms } \\
(\mathbf{N}=128)\end{array}$ & 3.66 & 0.33 & -0.72 & -2.62 & -6.91 & 1.27 & 0.82 & -2.79 & -0.94 & 7.91 \\
\hline \multicolumn{11}{|c|}{ Panel 3 - Differences Real frequency - BL frequencies, for large firms (above the median) } \\
\hline $\begin{array}{l}\text { Total obs. } \\
(\mathrm{N}=607)\end{array}$ & 1.04 & -0.19 & -1.82 & 1.10 & 0.51 & -0.28 & -0.77 & 1.83 & -0.68 & -0.76 \\
\hline $\begin{array}{l}\text { Profitable } \\
\text { firms } \\
(N=472)\end{array}$ & 0.95 & 1.75 & -1.77 & 0.16 & -0.07 & -1.41 & -0.65 & 1.77 & 0.15 & -0.87 \\
\hline $\begin{array}{l}\text { Loss firms } \\
(\mathbf{N}=135)\end{array}$ & 1.36 & -6.95 & -1.99 & 4.38 & 2.56 & 3.66 & -1.19 & 2.07 & -3.56 & -0.35 \\
\hline
\end{tabular}

Profitable firms above the median seem to follow the pattern of upward manipulation of the net income: more 0 and 1 and less 9 , although for the latter figure the difference is small and diminished further by the positive difference of the digit 8 . The frequencies of the digits 4 and 5 allow us to say that the rounding up through these figures is rather made by small companies. Large and deficit firms have less 8 and 9 - a sign of downward manipulation, confirmed by more 0 , but overruled by much less 1: there too, the possible manipulation by loss-making firms is far from the predictions we made in the hypothesis H2. The differences for large firms (especially for profitable ones), calculated by taking into account the first two and the last two digits, are different from the differences calculated for the smaller ones, less by the amplitude than by the sign of these deviations which goes in the direction of a upward manipulation. By analysing the standard deviations (not reported) calculated for the two categories of firms, we find, in fact, fewer possible manipulations for large firms. 


\subsection{Differences real vs. expected frequencies of the digits in the net income, according to the auditor category}

The available observations with the net income are 1,215. We identified the auditor for only 1,147 observations (Table 5), including 328 of Big N (28.6\%) and 819 of non-Big N (71.4\%). The second panel in Table 5 shows that companies audited by Big Ns have less 0 in the second position of net income. Even if the 9 are less numerous too, the upward manipulation does not seem to be confirmed. In fact, we can say that firms audited by Big $\mathrm{N}$ are more prudent. Unlike the previous results, the frequencies of digits 4 and 5 no longer suggest significant upward rounding. Profitable firms audited by Big $\mathrm{N}$ - being more numerous (72.3\%) show even more clear that there are few upward manipulations, even if there are many less 9 , but for more 3 and not 0 and 1 . Loss firms audited by Big $\mathrm{N}$ declare much less 0 and 1, for more 9 - this is a clear sign of upward manipulation, confirmed by the distributions of digits 4 and 5.

Table 5 - Differences between real frequencies and BL frequencies for the appearance of the digits in the second position of the net income, according to

the auditor category

\begin{tabular}{|c|c|c|c|c|c|c|c|c|c|c|}
\hline The digit & $\mathbf{0}$ & 1 & 2 & 3 & 4 & 5 & 6 & 7 & 8 & 9 \\
\hline $\begin{array}{l}\text { BL } \\
\text { Frequencies }\end{array}$ & 11.97 & $\begin{array}{c}11.3 \\
9\end{array}$ & 10.88 & $\begin{array}{c}10.4 \\
3\end{array}$ & $\begin{array}{c}10.0 \\
3\end{array}$ & 9.67 & 9.34 & 9.04 & 8.75 & 8.50 \\
\hline \multicolumn{11}{|c|}{ Panel 1 - Differences Real frequency - BL frequencies, for total observations containing the identity of the auditor } \\
\hline $\begin{array}{l}\text { Total obs. } \\
(\mathrm{N}=1,147)\end{array}$ & 0.15 & 0.03 & -0.51 & 0.21 & -1.05 & 0.53 & 0.34 & 1.33 & -0.90 & -0.13 \\
\hline $\begin{array}{l}\text { Profitable } \\
\text { firms } \\
(\mathrm{N}=\mathbf{8 9 5})\end{array}$ & -0.57 & 1.01 & -0.37 & -0.04 & -0.87 & 0.16 & 0.72 & 1.69 & -0.59 & -1.13 \\
\hline $\begin{array}{l}\text { Loss firms } \\
(N=252)\end{array}$ & 2.71 & -3.45 & -0.96 & 1.08 & -1.70 & 1.84 & -1.01 & 0.09 & -2.00 & 3.40 \\
\hline \multicolumn{11}{|c|}{ Panel 2 - Real Frequency Difference - BL Frequencies; Big $N$ auditor } \\
\hline $\begin{array}{l}\text { Total obs. } \\
(\mathrm{N}=328)\end{array}$ & -1.91 & -2.24 & 0.10 & 2.98 & 0.03 & 0.39 & 0.42 & 0.72 & 0.09 & -0.57 \\
\hline $\begin{array}{l}\text { Profitable } \\
\text { firms } \\
(\mathbf{N}=\mathbf{2 3 7})\end{array}$ & -2.27 & 0.42 & 1.36 & 2.65 & 0.52 & -0.81 & 0.36 & -0.18 & 0.11 & -2.17 \\
\hline $\begin{array}{l}\text { Loss firms } \\
(\mathrm{N}=91)\end{array}$ & -0.98 & -9.19 & -3.19 & 3.86 & -1.24 & 3.52 & 0.55 & 3.05 & 0.04 & 3.59 \\
\hline \multicolumn{11}{|c|}{ Panel 3 - Real Frequency Difference - BL Frequencies; non-Big $N$ auditor } \\
\hline $\begin{array}{l}\text { Total obs. } \\
(\mathrm{N}=819)\end{array}$ & 0.97 & 0.94 & -0.75 & -0.91 & -1.48 & 0.59 & 0.31 & 1.58 & -1.30 & 0.05 \\
\hline $\begin{array}{l}\text { Profitable } \\
\text { firms } \\
(\mathbf{N}=658)\end{array}$ & 0.04 & 1.22 & -1.00 & -1.01 & -1.37 & 0.51 & 0.84 & 2.36 & -0.85 & -0.75 \\
\hline $\begin{array}{l}\text { Loss firms } \\
(\mathrm{N}=161)\end{array}$ & 4.80 & -0.21 & 0.30 & -0.49 & -1.96 & 0.89 & -1.89 & -1.59 & -3.16 & 3.30 \\
\hline
\end{tabular}

In the case of profitable firms audited by non-Big $\mathrm{N}$, the orientation toward upward manipulations seems quite visible, even if we must take into account the 1 next to 0 . The pattern of the distribution of frequencies is upward for both 0 and 1, 9 and 8 , and 4 and 5. For deficit firms, the frequencies are quite irregular (much more 
irregular than for loss-making firms audited by Big N) and does not allow us to draw a clear conclusion about the meaning of possible manipulation.

These results confirm our hypothesis H3: firms audited by non-Big N (especially those with positive net income) seem to manipulate upward more than firms audited by Big N, so the presence of a Big N limit the earnings management, except for lossmaking firms. On the other hand, the range of deviations for companies audited by big $\mathrm{N}$ is greater than for other firms.

The observations available with a complete audit report (which contains the audit opinion) are even fewer (Table 6): 1,133, of which 751 with an unmodified opinion $(66.3 \%)$ and 382 with a modified opinion (most often a qualified opinion, but there are also some contrary opinions and even the disclaimer of opinion).

Table 6 - Differences between real frequencies and BL frequencies for the appearance of the digits in the second position of the net income, according to the type of the auditor's opinion

\begin{tabular}{|c|c|c|c|c|c|c|c|c|c|c|}
\hline The digit & $\mathbf{0}$ & 1 & 2 & 3 & 4 & 5 & 6 & 7 & 8 & 9 \\
\hline $\begin{array}{l}\text { BL } \\
\text { Frequencies }\end{array}$ & 11.97 & 11.39 & 10.88 & 10.43 & 10.03 & 9.67 & 9.34 & 9.04 & 8.75 & 8.50 \\
\hline \multicolumn{11}{|c|}{ Panel 1 - Differences Real frequency - BL frequencies, for total observations containing an audit opinion } \\
\hline $\begin{array}{l}\text { Total obs. } \\
(\mathbf{N}=1,133)\end{array}$ & 0.21 & 0.17 & -0.47 & 0.25 & -1.12 & 0.48 & 0.28 & 1.29 & -1.07 & -0.03 \\
\hline $\begin{array}{l}\text { Profitable } \\
\text { firms } \\
(\mathrm{N}=\mathbf{8 8 1})\end{array}$ & -0.51 & 1.21 & -0.32 & 0.01 & -0.95 & 0.09 & 0.65 & 1.63 & -0.80 & -1.01 \\
\hline $\begin{array}{l}\text { Loss firms } \\
(\mathrm{N}=\mathbf{2 5 2})\end{array}$ & 2.71 & -3.45 & -0.96 & 1.08 & -1.70 & 1.84 & -1.01 & 0.09 & -2.00 & 3.40 \\
\hline \multicolumn{11}{|c|}{$\begin{array}{l}\text { Panel } 2 \text { - Real Frequency Difference - BL Frequencies, for the observations containing a modified audit } \\
\text { opinion }\end{array}$} \\
\hline $\begin{array}{l}\text { Total obs. } \\
(\mathrm{N}=382)\end{array}$ & 1.64 & -2.23 & 0.64 & -1.01 & -1.13 & 0.02 & 0.87 & 2.48 & -2.47 & 1.19 \\
\hline $\begin{array}{l}\text { Profitable } \\
\text { firms } \\
(\mathbf{N}=251)\end{array}$ & 0.38 & 0.56 & 1.07 & -0.47 & -0.47 & -1.30 & 1.82 & 2.51 & -2.38 & -1.73 \\
\hline $\begin{array}{l}\text { Loss firms } \\
(N=131)\end{array}$ & 4.06 & -7.57 & -0.19 & -2.03 & -2.40 & 2.54 & -0.94 & 2.41 & -2.64 & 6.77 \\
\hline \multicolumn{11}{|c|}{$\begin{array}{l}\text { Panel } 3 \text { - Real Frequency Difference - BL Frequencies, for the observations containing an unmodified audit } \\
\text { opinion }\end{array}$} \\
\hline $\begin{array}{l}\text { Total obs. } \\
(\mathrm{N}=751) \\
\text { Profitable }\end{array}$ & -0.52 & 1.39 & -1.03 & 0.89 & -1.11 & 0.72 & -0.02 & 0.68 & -0.36 & -0.64 \\
\hline $\begin{array}{l}\text { firms } \\
(\mathrm{N}=630)\end{array}$ & -0.86 & 1.47 & -0.88 & 0.20 & -1.14 & 0.65 & 0.18 & 1.28 & -0.18 & -0.72 \\
\hline $\begin{array}{l}\text { Loss firms } \\
(\mathrm{N}=121)\end{array}$ & 1.25 & 1.01 & -1.79 & 4.45 & -0.94 & 1.07 & -1.08 & -2.43 & -1.31 & -0.24 \\
\hline
\end{tabular}

The net income presented by the firms receiving an unmodified opinion seem slightly manipulated upward, taking into account the pairs of digits 0 and 1,9 and 8 and 4 and 5. On the other hand, the loss-making firms with a clean opinion seem to manipulate downward: more 0 and 1, less 9 and 8 , less 4 and more 5. This behaviour 
may seem a bit odd, but it is in the direction of big bath accounting: in times of loss we are trying to make this loss heavier, in order to cover all kinds of future risks, more or less probable, and to show profits in a following year.

Profitable firms that have received modified opinions have frequencies of the digits in the second position of the net income which shows a certain tendency towards upward manipulation: more 0 and 1 and less 9 and 8; in the middle of the interval, there are less 4 , but also less 5 , which does not confirm the upward manipulation. The loss-making firms with a modified opinion reveal significant differences between the real frequencies and BL ones, but these differences are not systematically in the direction of a clear upwards or downwards manipulation. At the limit, by grouping 0 and 1, on one side, and 9 and 8 on the other, we could detect a certain orientation towards the increase of the income, which is not confirmed by the digits 4 and 5 .

The standard deviations calculated for the two categories of opinion are significantly lower in the case of firms receiving unmodified opinions, which suggests a better quality of the income presented by these firms.

\subsection{Differences real vs. expected frequencies of the digits in the net income, according to the CFO gender}

We identified the CFO's gender for 1,134 observations (Table 7): there are 627 women $(55.3 \%)$ and 507 men $(44.7 \%)$.

For profitable firms, the frequencies of the appearance of the digits 0 and 1 , on one side, and 9 and 8 , on the other, show us that women seem less prudent than men: even if the positive difference for the digit 0 is very small, the 9 and 8 are much less numerous - the explanation is an upwards rounding, confirmed by the differences in digits 4 and 5. For profitable firms whose the chief financial officer is a man, it is difficult to say that the difference would justify an upward adjustment: there are less 0 and they are not offset by the more 1 ; there are less 9 , but almost offset by more 8 . In the middle of the interval, less 4 are accompanied by less 5 , so handling is not really upward. For loss-making firms, even if the differences are not the same as for profitable firms, they have, for the most part, the same sense and are far from justifying the rounding up. In terms of standard deviations (not reported), the differences seem slightly higher in the case of firms whose chief financial officer is a man. 
Table 7 - Differences between real frequencies and BL frequencies for the appearance of the digits in the second position of the net income, according to the CFO gender

\begin{tabular}{|c|c|c|c|c|c|c|c|c|c|c|}
\hline The digit & $\mathbf{0}$ & 1 & 2 & 3 & 4 & 5 & 6 & 7 & 8 & 9 \\
\hline $\begin{array}{l}\text { BL } \\
\text { Frequencies }\end{array}$ & 11.97 & 11.39 & 10.88 & 10.43 & 10.03 & 9.67 & 9.34 & 9.04 & 8.75 & 8.50 \\
\hline \multicolumn{11}{|c|}{$\begin{array}{l}\text { Panel } 1 \text { - Differences Real frequency - BL frequencies, for all the observations with an available } \\
\text { information about the CFO gender }\end{array}$} \\
\hline $\begin{array}{l}\text { Total obs. } \\
(\mathrm{N}=1,134) \\
\text { Profitable }\end{array}$ & 0.11 & 0.07 & -0.21 & -0.02 & -1.12 & 0.56 & 0.18 & 1.45 & -0.81 & -0.21 \\
\hline $\begin{array}{l}\text { firms } \\
\text { 891) }\end{array}$ & -0.75 & 0.96 & -0.11 & -0.22 & -1.05 & 0.32 & 0.76 & 1.73 & -0.56 & -1.09 \\
\hline $\begin{array}{l}\text { Loss firms } \\
(\mathrm{N}=\mathbf{2 4 3})\end{array}$ & 3.26 & -3.16 & -0.59 & 0.68 & -1.39 & 1.44 & -1.93 & 0.43 & -1.75 & 3.02 \\
\hline \multicolumn{11}{|c|}{ Panel 2 - Differences Real frequency - BL frequencies, for the observations with a male CFO } \\
\hline $\begin{array}{l}\text { Total obs. } \\
(\mathrm{N}=\mathbf{5 0 7})\end{array}$ & -0.92 & -0.15 & -0.62 & 0.81 & -1.35 & -0.60 & 0.13 & 2.20 & 0.72 & -0.22 \\
\hline $\begin{array}{l}\text { Profitable } \\
\text { firms }(N= \\
403)\end{array}$ & -1.80 & 1.27 & -0.46 & 0.74 & -0.85 & -1.48 & 0.34 & 2.62 & 0.93 & -1.30 \\
\hline $\begin{array}{l}\text { Loss firms } \\
(\mathrm{N}=507)\end{array}$ & 2.45 & -5.62 & -1.26 & 1.11 & -3.30 & 2.83 & -0.69 & 0.58 & -0.10 & 4.00 \\
\hline \multicolumn{11}{|c|}{ Panel 3 - Differences Real frequency - BL frequencies, for the observations with a female CFO } \\
\hline $\begin{array}{l}\text { Total obs. } \\
(N=627) \\
\text { Profitable }\end{array}$ & 0.95 & 0.25 & 0.12 & -0.70 & -0.94 & 1.49 & 0.23 & 0.85 & -2.05 & -0.21 \\
\hline $\begin{array}{l}\text { firms }(n= \\
488)\end{array}$ & 0.12 & 0.70 & 0.19 & -1.00 & -1.22 & 1.81 & 1.11 & 1.00 & -1.78 & -0.92 \\
\hline $\begin{array}{l}\text { Loss firms } \\
(\mathbf{N}=139)\end{array}$ & 3.86 & -1.32 & -0.09 & 0.36 & 0.04 & 0.40 & -2.87 & 0.31 & -2.99 & 2.29 \\
\hline
\end{tabular}

\section{Conclusions, limitations and further research}

The research on earnings management uses several techniques for the identification and the measurement of the accounting numbers manipulation. Benford's law establishes that the frequencies of the appearance of digits from 0 to 9 in a number are, in a multitude of cases, fixed. There are so far many studies that mobilize the BL to check whether the distribution of digits in the financial indicators - especially in the net income - corresponds to the expected frequencies proposed by this law. The differences between the specific frequencies at the BL frequencies observed for the listed firms may suggest manipulations of the income. When, in second position of the reported income, there are more 0 and, possibly, 1 and less 9 and, possibly, 8 , in the case of profitable firms, it can be concluded that there is an artificial increase in reported net income. In many studies, the authors find such upward manipulations of the income or of other accounting numbers. However, Shi et al. (2018) conclude that using the BL in verifying the accuracy of data and in identifying frauds or errors must be completed with some other tests. 
To our knowledge, there is, so far, no analysis of the frequency of the digits as they appear in the net income reported by the Romanian listed companies. Thus, our goal is to apply the $\mathrm{BL}$ in order to compare the expected frequencies that it proposes to the real frequencies of the occurrence of digits in second position of the net income for more than 1,200 observations - non-financial companies listed on the BSE, in the 2001-2017 period. We analysed the individual financial statement. In order to better observe the evolution of Romanian accounting standards and the influence of these changes on the quality of the information reported, we have divided the total period into three sub-periods: 2001-2005 - first attempt to apply the IAS; 2006-2011 application of Romanian accounting standards in line with European directives; 2012-2017 - application of IFRS. After testing the net income, for the entire period and by sub-period, we checked how some variables influenced the distribution of digits in the net income: the size of the companies, the category of auditor, the audit opinion, and the CFO gender. By following the results already presented in the literature, our hypotheses go in the direction of the identification of upward manipulations of the net income, with an improvement of the differences between real frequencies and BL frequencies, as and when the evolution accounting standards (H1), less manipulation in the case of large firms (H2), better quality of income reported by companies audited by Big $\mathrm{N}$ (H3), more prudence of female CFO compared to men who hold the same position.

The hypothesis H1a is not really confirmed: the differences between the real frequencies and the expected frequencies do not seem to suggest systematic upward manipulations. It is only in the case of digits 4 (with fewer appearances) and 5 (with more appearances) that our hypothesis could be considered valid. The evolution of the accounting standards shows us that, indeed, during the first period, the differences between the two frequencies are important, but rather suggesting a tendency towards the decrease of the income. During the second period, the evolution of accounting standards and the improvement of the application of these standards, accompanied by a certain accounting-tax disconnection led to less significant differences between the real frequencies and BL ones, more stability in these deviations and an orientation towards possible upward manipulations of the income. Differences greater than during the second period (although lower than those of the first period) are found for the IFRS interval, with an orientation towards the rounding up of incomes.

By analysing small firms, we find that the upward manipulation is not confirmed for these companies, except in the case of digits 4 and 5. On the contrary, for large firms, the sense of the differences suggests possible upward adjustments, in the case of profitable firms, while for deficit-making firms, the differences appear irregular and rather inconsistent. Thus, hypothesis $\mathrm{H} 2$ is not confirmed.

Companies audited by Big $\mathrm{N}$ have the reputation of providing less manipulated information. Indeed, the difference between the real frequencies and the expected 
BL frequencies for these firms show that they seem more prudent, with more significant signs of upward manipulation for loss-making firms. The results confirm our hypothesis H3: firms audited by non-Big Ns (especially profitable ones) seems to manipulate upward the net income more than firms audited by Big N. By retaining the variable audit opinion, in the case of unmodified opinions, the manipulations seem slightly on upward, except for loss-making firms. Profitable firms that have received modified opinions also point to larger upward adjustments, while for lossmaking firms there are manipulations, but their direction does not seem very clear.

Our hypothesis $\mathrm{H} 4$ is not confirmed: the net income of firms whose the financial director is a woman seem less prudent, more upward manipulated than the income reported by firms whose financial director is a man.

The limits of our study include the limited number of observations taken into account, the fact that we have not mobilized powerful statistical instruments to determine the significance of the differences calculated and the fact that we have analysed only one indicator - the net income. On the other hand, we analyse the numbers as they appear in the financial statements, without any transformation. Balanzario \& Sanchez-Ortiz (2010) found two processes by way of which a random variable can come close to following BL: the multiplication or the exponentiation of the variable to a large power: we did not apply such a robustness test. All these limits represent so many fields for future research.

\section{References}

Alali, F. A. \& Romero, S. (2013) "Benford's Law: Analyzing a Decade of Financial Data", Journal of Emerging Technologies in Accounting, vol. 10, no. 1: 1-39

Albu, C. N., Albu, N. \& Alexander, D. (2014) "When global accounting standards meet local context - Insights from an emerging economy", Critical Perspectives on Accounting, vol. 25, no. 6: 489-510

Amiram, D. Bozanic, Z. \& Rouen, E. (2015) "Financial statement errors: evidence form the distributional properties of financial statements numbers", Review of accounting studies, vol. 20, no. 4: 1540-1593

Aono, J. \& Guan, L. (2008) "The impact of Sarbanes-Oxley Act on cosmetic earnings management", Research in Accounting Regulation, vol. 20: 205-2015

Archambault, J. J. \& Archambault, M. E. (2011) "Earnings management among firms during the pre-SEC era: a Benford's Law analysis", The Accounting Historian Journal, vol. 38, no. 2: 145-170

Bader, A. A. \& Saleh, M. M. A. (2017) "Evidence on the Extent of Cosmetic Earnings and Revenues Management by Jordanian Companies", International Journal of Economics and Financial Issues, vol. 7, no. 3: 20-30 
Balaciu, D. E., Bogdan, V., Meșter, I. T. \& Gherai, D. (2012) "Empirical evidences of Romanian auditors behavior regarding creative accounting practices", Accounting and Management Information Systems, vol. 11, no. 2: 213-238

Balanzario, E. P., \& Sanchez-Ortiz, J. (2010) "Sufficient conditions for Benford's law”, Statistics \& Probability Letters, vol. 80, no. 23-24, pp. 1713-1719

Barua, A., Davidson, L. F., Rama, D. V. \& Thiruvadi, S. (2010) "CFO Gender and Accruals Quality", Accounting Horizons, vol. 24, no. 1: 25-39

Brad, L., Dobre, F., Țurlea, C. \& Brașoveanu, I. V. (2014) "The impact of IFRS adoption in Romania upon the earnings management of the Bucharest Stock Exchange entities", Procedia Economics and Finance, vol. 15: 871-876

Burcă, V. \& Mateș, D. (2015) "Implications of IFRS adoption on earnings quality, empirical case for Romanian environment", Annales Universitatis Apulensis Series Oeconomica, vol. 17, no. 1: 58-81

Carp, M. (2015) "The impact of the transition to IFRS on the quality of earnings reported by Romanian listed companies”, Audit Financiar, vol. XIII (8-128): 79-93

Carslaw, C. A. P. N. (1988) "Anomalies in income numbers: evidence of goal oriented behaviour", The Accounting Review, vol. 63, no. 2: 321-327

Dang, L. He, D. (2017) "Does mandatory IFRS convergence constrain rounding manipulations in accounting? Evidence from Chinese firms", International Journal of Managerial and Financial Accounting, vol. 9, no. 1: 1-18

De George, E. T. \& Shivakumar, L. (2016) "A review of IFRS adoption literature", Review of Accounting Studies, vol. 21, no. 3: 898-1004

Del Baldo, M., Tiron-Tudor, A. \& Faragalla, W. A. (2019) "Women's role in the Accounting professions: a comparative study between Italy and Romania", Administrative Sciences vol. 9, no. 2 doi:10.3390/admsci9010002

Gajevsky, A. (2015) "Assessing financial reporting quality", Audit Financiar, vol. XIII (1-121): 69-80

Garza-Gomez, X, Dong, X. \& Yang, Z. (2015) "Unusual patterns in reported segment earnings of US firms", Journal of Applied Accounting Research, vol. 16, no. 2: 287-304

Geyer, D. \& Drechsler, C. (2014) "Detecting Cosmetic Debt Management Using Benford's Law", The Journal of Applied Business Research, vol. 30, no. 5: $1-8$

Guan, L., He, S. \& McEldowney, J. (2008) "Windows dressing in reported earnings", Commercial Lending Review, vol. 23, no. 3: 28-33

He, D., Koo, M. \& Guan, L. (2013) "Rounding in reported earnings and revenues", International Journal of Management, vol.30, no. 3, part 1: 43-54

Hogan, C. E., Rezaee, Z., Riley Jr. R. A. \& Velury, U. K. (2008) "Financial statement fraud: insights from the academic literature", Auditing: a Journal of Practice \& Theory, vol. 27, no. 2: 231-252

Huian, C., Mironiuc, M. \& Chiriac, M. (2018) "Study on the association between earnings management and value relevance based on the reporting method used for operating cash flows", Audit Financiar, vol. XVI (1-149):101-110 
Ionașcu, M., Ionașcu, I., Săcărin, M. \& Minu, M. (2014) "IFRS adoption in developing countries: the case of Romania", Accounting and Management Information Systems, vol. 13, no. 2: 311-350

Istrate, C. (2006) "Quelques observations sur l'application des IAS/IFRS en Roumanie", Accounting and Management Information Systems, vol. 4, suppl.: $128-135$

Istrate, C. (2011) "Evolutions in the accounting-taxation (dis)connection in Romania, after 1990", Review of Economics and Business Studies, vol. 4, no. 2: 43-61

Istrate, C., Georgescu, I. E., Carp, M., Robu, I. B. \& Păvăloaia, L. (2015) “Accruals earnings management in emerging market sunder the transition to IFRS: the case of Romanian listed companies", Transformations in Business \& Economics, vol. 14, no. 2A-35A: 42-59

Ivan, I. (2015) "Ways to detect creative accounting techniques by studying cash flows", Audit Financiar, vol. XII, no. 8: 94-102

Jiang, H., Hu, Y., Zhang, H. \& Zhou, D. (2018) "Benfits of downward earnings management and political connection: evidence from Governmenet Subsidy and market pricing", International Journal of Accounting, vol. 53, no. 4: 255-273

Jordan, C. E., Clark, S. J. \& Pate, G. R. (2008) "Earnings manipulation to achieve cognitive reference points in income", Academy of Accounting and Financial Studies Journal, vol. 12, no. 3: 97-112

Jordan, C. E., Clark, S. J. \& Waldron, M. A. (2014) "Cosmetic earnings management before and after corporate governance legislation in Canada", Accounting and Finance Research, vol. 3, no. 4: 105-114

Kinnunen, J. \& Koskela M. (2003) "Who is Miss World in cosmetic earnings management? A cross-national comparison of small upward rounding of net income numbers among eighteen countries", Journal of International Accounting Research, vol. 2, no. 1: 39-68

Kumar, S. B., Goyal, V. \& Mitra, S. K. (2018) "Do indian firms manage earning number? An empirical investigation", Academy of Accounting and Financial Studies Journal, vol. 22, no. 1: 1-7

Lacina, M., Lee, B. B. \& Kim, D. W. (2018) "Benford's law and the effects of the Korean financial reforms on cosmetic earnings management", Journal of International Accounting, Auditing and Taxation, vol. 30, pp. 2-17

Lolbert, T. (2008) On the non-existence of a general Benford's law", Mathematical Social Sciences, vol. 55, no. 2, pp. 103-106

Nechita, E. (2015) "Earnings management and quality of financial reporting: a prepost IFRS adoption comparative analysis for companies listed on the Bucharest Stock Exchange", Audit Financiar, vol. 2, (122): 74-84

Nigrini, M. J. (2005) "An assessment of the change in the incidence of earnings management around the Enron-Andersen episode", Review of Accounting and Finance, vol. 4, no. 1: 92-110

Peni, E. \& Vähämaa, S. (2010) "Female executives and earnings management", Managerial Finance, vol. 36, no. 7: 629-645 
Riccioni, J. \& Cerqueti, R. (2018) "Regular paths in financial markets: investigating the Benford's law", Chaos, Solitons \& Fractals, vol. 107, pp. 186-194

Roxas, M. L. (2011) "Financial statement fraud detection using ratio and digital analysis", Journal of Leadership, Accountability and Ethics, vol. 8, no. 4: $56-66$

Shi, J., Ausloos, M. \& Zhu, T. (2018) "Benford's law first significant digit and distribution distances for testing the reliability of financial reports in developing countries", Phisica A: Statistical Mechanics and its Applications, vol. 492, pp. 878-888

Skousen, C. J., Guan, L. \& Wetzel, T. S. (2004) "Anomalies and unusual patterns in reported earnings: Japanese managers round earnings", Journal of International Financial Management and Accounting, vol. 15, no. 3: 212-234

Thomas, J. K. (1989) "Unusual patterns in reported earnings", The Accounting Review, vol. 64, no. 4: 773-787

Van Caneghem, T. (2004) "The impact of audit quality on earnings roundingbehavior: some UK evidence", European Accounting Review, vol. 13, no. 4: 771-786

Vladu, B. A., Amat, O. \& Cuzdriorean, D. D. (2017) „Truthfulness in accounting: how to discriminate accounting manipulators from non-manipulators", Journal of Business Ethics, vol. 140, no. 4: 633-648

Whyman, G., Shulzinger, E. \& Bormashenko, E. (2016) "Intuitive considerations clarifying the origin and applicability of the Benford law", Results in Physics, vol. 6: 3-6

Yan, X., Yang, S. G., Kim, B. J. \& Minnhagen, P. (2018) "Benford's law and first letter of words", Phisica A: Statistical Mechanics and its Applications, vol. 512: 305-315

${ }^{\mathrm{i}}$ Thus, the measurement of the quality of financial information is carried out using techniques such:

- the variability of net income in relation to the variability of total assets or the change in cash flow, the comparison of flows with the accruals (Brad et al., 2014; Nechita, 2015);

- the Jones' model of identifying discretionary accruals, complemented by the Dechow model (Carp, 2015);

- the Dechow model and the Kothari model (Gajevsky 2015);

- the Dechow and Dechow \& Dichev models (Istrate et al., 2015);

- the Callao model (Huian et al., 2018);

- modified Jones models, Dechow, Kothari \& Jones, Ball \& Shivakumar (Burcă \& Mateş 2015).

ii Kinnunen and Koskela (2003) found $73.8 \%$ profitable firms and $26.2 \%$ loss firms, with the largest proportion of firms with losses in the USA (34\%) and the least important in Finland $(8.2 \%)$

iii There are other studies that analyse sub-periods (Alali \& Romero 2013, Dang \& He 2017; Lacina et al., 2018), the transition from one sub-period to another being marked by an important event such as the transition to IFRS (voluntary or mandatory), the application of 
the stricter financial supervision rules ( $\mathrm{SOX}$ and/or its equivalents), the radical change due to some other radical financial reform.

${ }^{\text {iv }}$ For the periodization of the evolutions in the Romanian accounting and financial reporting systems, we rely to Ionaşcu et al. (2014), Albu et al. (2012) and Istrate (2011).

v Ullman and Watrin (2017) agree that this is not a natural law, but rather regularly observed frequencies.

vi At the present time, there are only four Big N, but in the first year of the selected interval (2001), there were audit reports signed by auditors belonging to the firm Arthur Andersen.

vii To test the compliance of real frequencies with those provided by the BL, Skousen et al. (2004) use the Z-statistical test, as do Dang \& He (2017), Van Caneghem (2004), Guan et al. (2008), He et al. (2013), Jordan et al. (2014). Other authors retain several tests: Archambault \& Archambault (2011) - chi-square and t-statistic, Carslaw (1988) Z-statistic and chi-square, Bader \& Saleh (2017) - z-statistics, MAD test and chi-square test, Nigrini (2005) - chi-square and MAD (mean absolute deviation). 